\title{
ПЕРСПЕКТИВИ ВИКЛАДАННЯ УРОЛОГІЇ В БУКОВИНСЬКОМУ ДЕРЖАВНОМУ МЕДИЧНОМУ УНІВЕРСИТЕТІ
}

\author{
O. S. Fedoruk, I. I. Ilyuk, V. I. Zaitsev, K. A. Vladychenko, V. T. Stepan, V. V. Visnyuk \\ Bukovynian State Medical University, Chernivtsi

\section{PERSPECTIVES OF TEACHING OF UROLOGY IN BUKOVYNIAN STATE MEDICAL UNIVERSITY}

\begin{abstract}
Мета дослідження - проаналізувати стан викладання урології в БДМУ, визначити слабкі місця в навчальному процесі та можливі напрямки їх удосконалення.

Матеріали та методи дослідження. Нами проаналізовано особливості викладання урології на тлі сучасних вимог навчального процесу та вимог до підготовки майбутнього лікаря-уролога.

Результати й обговорення. В результаті аналізу визначено слабкі місця при викладанні урології на сучасному рівні, до яких можна віднести недостатнє впровадження в навчальний процес сучасних технологічних систем підготовки та сучасних тренажерів, а також ряд проблем, пов’язаних із викладанням студентам англійською мовою.

Висновки. Ефективне розв'язання викликів сучасної охорони здоров'я потребує високого рівня фахової підготовки спеціалістів-урологів, проведення цілеспрямованих організаційно-методичних та педагогічних заходів в усіх розділах підготовки лікаря-уролога, пріоритетом яких є підвищення кваліфікації та практичних фахових умінь, широке використання у навчальновиховному процесі інноваційних технологій навчання.
\end{abstract}

Ключові слова: навчання; урологія; практичні навички.

The aim of the study - to analyze teaching state of Urology in BSMU, to find out weak points in educational process and possibilities for its improvement.

Matherials and Methods. The peculiarities of teaching of Urology in Bukovynian State Medical University according to modern tendencies of urologist's graduation in Ukraine and worldwide were analyzed.

Results and Discussion. The main directions in theoretical and practical education which need to be improved are implementation of modern systems for training and solving of additional problems for English-speaking students.

Conclusions. Effective answering for challenging tasks of health care system needs teachers and urologists appropriate level of education and knowledge with usage of modern educational technologies.

Key words: education; urology; practical skills.

Вступ. Основне завдання, яке держава ставить перед будь-яким вищим навчальним закладом, - це провадження освітньої діяльності на високому рівні, що забезпечить здобуття особами вищої освіти відповідного ступеня за обраними спеціальностями [1]. Освітній процес - це інтелектуальна, творча діяльність у сфері вищої освіти і науки, що проводиться у вищому навчальному закладі через систему науково-методичних і педагогічних заходів та спрямована на передачу, засвоєння, примноження і використання знань, умінь та інших компетентнос-

(c) О. С. Федорук, І. І. Ілюк, В. І. Зайцев та ін. тей в осіб, які навчаються, а також на формування гармонійно розвинутої особистості [2].

Надання ефективної урологічної допомоги на сучасному етапі потребує відповідного рівня фахової підготовки спеціалістів - урологів, особливо враховуючи, що останніми роками відбувається різке наростання обсягу наукових знань з урології. Це вимагає відповідних методичних та педагогічних заходів в усіх розділах підготовки лікаря-уролога, пріоритетом яких є підвищення практичних фахових умінь. Основною у формуванні майбутніх фахівців стала практична підготовка, яка формується під час відпрацювання навичок із використанням 
сучасних технологій у діагностичній лабораторії, на базі медичних закладів біля крісла чи ліжка хворого. Контроль якості опанування практичних навичок проводиться під час лікування пацієнтів, а також за допомогою комп’ютерних інтерактивних технологій [3].

Рівень розвитку урологічної науки та пов’ язаних з нею сучасних технологій у всьому світі, особливо в США та країнах Європейського Союзу, дає змогу досягти значних успіхів у подоланні урологічних захворювань та постійно зростає. Сучасна діагностика та лікування з використанням ендоскопічних і лапароскопічних технологій має широкий спектр застосування у клінічній практиці та займає пріоритетне місце в сучасній урології. Найбільш суттєвого значення вона набуває під час діагностики й лікування сечокам'яної хвороби та онкоурологічних захворювань.

Мета дослідження - проаналізувати реальний стан викладання урології в БДМУ, визначити слабкі місця в навчальному процесі та можливі напрямки їх удосконалення.

Матеріали та методи дослідження. Нами проаналізовано особливості викладання урології, перш за все як хірургічної дисципліни, на тлі сучасних вимог навчального процесу та вимог до підготовки майбутнього лікаря-уролога в аспекті змін, які відбуваються у національній системі охорони здоров'я.

Результати й обговорення. Проведений аналіз показав, що тенденції сучасної медицини висувають нові виклики для підготовки студентів. Вони полягають, перш за все, в тому, що натепер головним напрямком підготовки спеціаліста-медика, особливо хірургічного профілю, є практична підготовка. Саме на неї відводиться левова частка годин навчального процесу. Водночас якісна практична підготовка вимагає відповідного оснащення навчальних аудиторій та операційних на клінічній базі, що ми не завжди бачимо в реальних умовах. Недостатня кількість у закладах охорони здоров’я обладнання для ендоскопічної та лапароскопічної діагностики й лікування i, як наслідок, недостатня кількість проведених діагностичних та лікувальних процедур спричинені багатьма факторами, один 3 яких - невідповідність сучасним вимогам системи підготовки фахівців з ендоскопічної та лапароскопічної урології.

Орієнтація на сучасні практичні навички вимагає постійного удосконалення самого процесу навчання. Відповідно до вимог підготовки фахівців в Європейському освітньому просторі, важливого значення для вдосконалення освітнього процесу набуває подальше впровадження в навчальний процес сучасних технологічних систем підготовки, які включають широкий спектр сучасних практично орієнтованих технологій та методів, таких, як: технології проблемно-орієнтованого навчання; інтегрованого навчання; міждисциплінарні технології, тренінгові технології; імітаційні, рольові, ігрові технології; технології фундаментальної медичної освіти; особистісно-орієнтовані технології навчання; технології кредитно-модульні; технології діагностики якості; технології організації самостійної роботи студентів; інформаційні технології. При цьому необхідна адекватна міждисциплінарна інтеграція при викладанні профільної дисципліни із попередніми базовими та наступними суміжними дисциплінами відповідно до цілей підготовки фахівців різних спеціальностей (факультетів) [4]. Урологія на сучасному етапі перетворилася на складний союз науки та практики, що пов'язано із науково-технічним прогресом і все більшим удосконаленням технічних засобів діагностики та лікування. Все це, безумовно, вимагає перебудови змістовної основи освітнього процесу при збереженні позитивних якостей традиційних методів підготовки фахівців, здатних до самостійної діяльності.

Головною метою навчання студентів при вивченні урології є, перш за все, повне засвоєння базових знань і навичок з даної дисципліни. Зрозуміло, що тільки одиниці в подальшому будуть урологами, але кожен студент після закінчення урології, передусім, повинен володіти такими навичками, як катетеризація сечового міхура та ректальне обстеження простати. Крім того, студент повинен вміти надати ургентну допомогу пацієнтам з урологічною патологією і розуміти принципи діагностики та лікування головних урологічних захворювань. На лекціях і практичних заняттях студентів ознайомлюють із можливостями використання сучасних методів діагностики і консервативного та хірургічного лікування у клінічній і поліклінічній практиці, вчать складати алгоритм урологічного обстеження, самостійно розпізнавати за матеріалами урологічного обстеження низку патологічних станів, що вимагають невідкладної діагностики та лікування. Отримані знання поглиблюються і закріплюються під час проходження клінічних дисциплін на старших курсах, де урологічні проблеми розглядаються у взаємозв'язку з конкретними питаннями клінічної діагностики та лікування хворих. 
Важливим моментом є раціональне планування заняття. Для цього використовуються сучасні методи тестового контролю з використанням питань англомовних іспитів, які стосуються урології. Всі дані питання завантажені на сайт Moodle, де кожен студент при підготовці до занять може пройти пробне тестування та визначити свій рівень знань. На даному сайті також завантажена література та посилання на інтернет-ресурси, які дозволяють більш глибоко підготуватись 3 різних тем урології. При проведенні занять студенти проходять обов'язковий тестовий контроль, що є більш об'єктивним методом оцінювання знань та дозволяє більше часу приділити опрацюванню практичних навичок.

Слід також зважати на те, що більшість практичних хірургічних навичок студентам неможливо засвоїти безпосередньо на пацієнті, тому останніми роками все більшого значення набуває доступ до сучасних тренажерів та манекенів. Враховуючи їх велику вартість, особливо для тренажерів з моделюванням ендоскопічних маніпуляцій та операцій, важливим напрямком удосконалення практичної підготовки $€$ поступове оснащення навчальних кімнат відповідним обладнанням. На жаль, альтернативи цьому немає і такі інвестиції слід поступово робити, інакше рівень практичної підготовки наших студентів не буде відповідати сучасним стандартам.

Певною проблемою $є$ навчання англомовних студентів. Відсутність володіння українською або російською мовою у більшості студентів спричиняє неможливість прямого спілкування з пацієнтами, при якому викладач повинен бути присутнім у якості викладача. Крім того, не кожен пацієнт висловлює бажання бути оглянутим іноземним студентом. Тому при навчанні англомовних студентів викладачу доводиться дещо змінювати методику проведення занять, адаптуючи їі до певних реалій.

Одним із можливих варіантів залучення клінічних баз із відповідним сучасним обладнанням $€$ укладання угод з приватними клініками. Для цього $€$ доцільним пошук кваліфікованих спеціалістів 3 таких клінік та їх підготовка в якості викладачів. Це

\section{Список літератури}

1. Закон України “Про вищу освіту” від 01.07.2014 р. № 1556-VII (Редакція станом на 1.07.2014). - zakon. Rada.gov.ua.

2. Поляченко Ю. В. Медицинское образование в мире и в Украине / Ю. В. Поляченко, В. Г. Передерий, А. П. Волосовець. - Харьков : ИПП Контраст, 2005. - 462 с. дозволить розширити можливості практичного засвоєння навичок студентами та покращить матеріальну базу для викладання без значних фінансових вливань. Така практика давно існує в розвинутих країнах і вигідна як навчальним установам, так і приватним клінікам. Ще однією важливою умовою якісного викладання урології $є$ відповідний рівень власне викладачів. Натепер левова частина сучасних знань до нас потрапляє з розвинутих країн Європи та США та для їх адекватного засвоєння необхідне знання англійської мови. Крім того, важливим елементом є післядипломна освіта викладачів у вигляді відвідувань міжнародних конгресів та стажування за кордоном. Приміром, щорічні конгреси Європейської асоціації урологів збирають 10-15 тис. спеціалістів з усього світу, але їх відвідують тільки окремі фахівці з України, що явно не відповідає сучасним потребам. Подальший розвиток такого взаємообміну $є$ важливою запорукою відповідного рівня викладачів, які повинні готувати фахівців на сучасному рівні.

Висновки. Надання ефективної урологічної допомоги на сучасному етапі потребує високого рівня фахової підготовки спеціалістів-урологів, проведення цілеспрямованих організаційно-методичних заходів по підготовці лікаря-уролога, пріоритетом яких є підвищення кваліфікації та практичних фахових умінь, широке використання у навчально-виховному процесі інноваційних технологій навчання.

Колектив кафедри урології та нейрохірургії ВДНЗ України “Буковинський державний медичний університет” працює над підвищенням якості підготовки лікарів-урологів, що дозволить оптимізувати освітню діяльність у сучасних умовах згідно зі стандартами вищої медичної освіти.

Перспективи подальших досліджень. Для подальшого покращання підготовки студентів з урології необхідне постійне удосконалення методики викладання та матеріально-технічної бази навчальних закладів із постійним взаємообміном як студентами, так і викладачами з провідними навчальними закладами Європи та світу.

3. Доценко В. І. Інформаційно-комп’ютерні технології як засіб підвищення ефективності навчально-пізнавальної діяльності студентів / В. І. Доценко, Ю. П. Ткаченко // Інноваційні освітні технології у підготовці медичних кадрів. - Полтава, 2010. - С. 59-61. 
4. Мечев Д. С. Зміни в системі післядипломної освіти згідно із Законом України “Про вищу освіту” / Д. С. Ме-

\section{References}

1. Zakon Ukrainy “Pro vyshchu osvitu” vid 01.07.2014 r. No 1556-VII [Law of Ukraine “On Higher Education” from 01.07.2014 No 1556-VII]. zakon.Rada.gov.ua [in Ukrainian].

2. Poliachenko, Yu.V., Perederiy, V.G., \& Volosovets, A.P. (2005). Medytsynskoe obrazovaniye $v$ mire i v Ukraine [Medical education in the world and in Ukraine]. Kharkiv: IPP Kontrast [in Russian].

3. Dotsenko, V.I., \& Tkachenko, Yu.P. (2010). Informatsiino-kompiuterni tekhnolohii yak zasib pidvyshchennia efektyvnosti i navchalno-piznavalnoi diialnosti studen- чев, М. М. Ткаченко // Радіол. вісн. - 2014. - № 4. С. $43-46$. tiv. [Information and computer technology as a means of improving the teaching and learning of students]. Innovatsiyni osvitni tekhnolohii u pidhotovtsi medychnykh kadriv - Innovative educational technologies in training medical personnel. (pp. 59-61). Poltava [in Ukrainian].

4. Mechev, D.S., \& Tkachenko, M.M. (2014). Zminy v systemi pisliadyplomnoi osvity zhidno iz Zakonom Ukrainy "Pro vyshchu osvitu" [Changes in postgraduate education according to the Law of Ukraine "On higher education”]. Radiol. visnyk - Radiology Journal, 4, 43-46.

Електронна адреса для листування: vladychenko@rambler.ru 